\title{
Questioning State Corporations as Special Forms of Legal Entities
}

\author{
Submitted 19/01/19, 1st revision 23/03/19, 2nd revision 17/04/19, accepted 04/06/19
}

\begin{abstract}
Shashkova A.V. ${ }^{1}$, Polovchenko K.A. ${ }^{2}$, Volevodz A.G. ${ }^{3}$
Abstract:

Purpose: The idea of the present article lies in the research of the problem of the state regulation of legal entities with state participation.

Design/Methodology/Approach: The subject of the study is based on the regulatory legal acts defining the legal status of state corporations, the legal status of their property and funds, and the legal regulation of financial control over their activities. The legal basis of the research is in the norms of constitutional, financial, administrative and civil law.

Findings: The authors presented the overall analysis of the estate corporations, their competitive advantages, the effectiveness of the use of their powers and the value of the corporate social responsibility they promote.

Practical Implications: The value of the article is to advice on amending Russian legislation and law enforcement practice to make state corporations accountable to the state.

Originality/Value: The main contribution of the study is the detailed analysis of state corporations' business activity as well as their organizational and legal form. Authors suggested justified amendments to be introduced to the legislation and regulatory acts of the Russian Federation.
\end{abstract}

Keywords: Public enterprise governance, personnel economics, regulation, Russian legislation, Government owned.

JEL Codes: K230, L320, M1.

Paper Type: Research article in Special Issue Dedicated to Russian Economy.

Section 5: Law, Constitutional, Social.

\footnotetext{
${ }^{1}$ Doctor of Science (Politics), Candidate of Science (Law), Professor of Constitutional Law Chair, Moscow State Institute of International Relations (University) (MGIMO-University), Moscow, a.shashkova@inno.mgimo.ru

${ }^{2}$ Candidate of Science (Law), Associate Professor of Constitutional Law Chair, Moscow State Institute of International Relations (University) (MGIMO-University), Moscow, k.polovchenko@inno.mgimo.ru.

${ }^{3}$ Doctor of Science (Law), Vice Dean for Scientific Affairs of The International Law School, Head of the Department of Criminal Law, Criminal Procedure and Criminalistics, Moscow State Institute of International Relations (University) (MGIMO-University), Moscow, a.volevodz@inno.mgimo.ru
} 


\section{Introduction}

The Russian Federation suffered a period of transformation from the domination of state property to private property via privatisation. This process was painful and lacked transparency and any semblance of fairness. However, one can state that by the beginning of the 2000s the economic system was stable, the stream of investments into the country was growing and property rights were affirmed (Pond, 2018).

At the same time in the beginning of the 2000's, the creation of corporations with state participation (state corporations) took place in the Russian Federation. Objectively the country suffered no necessity of counter-transformation to state property forms again. Though the emerged idea resulted in powerful state legal entities to control most lucrative areas of the Russian Federation. The Deposit Insurance Agency (DIA) was formed in 2004, Vnesheconombank (VEB) was formed in 2007, and Roskosmos was formed in 2015. Seven state corporations were established in Russia up to the year 2017. One of the newly created state legal entities, the state corporation Olimpstroy, ceased to exist in 2014 (after the Olympic Games held in Sochi, Russia).

According to the OECD assessment, more than a fifth of the world's largest companies are state-owned. Such state-owned enterprises have an important place in the global economy and a key role in finance and natural resource distribution. They can have different forms. The benefits of state corporations lie within economic, political and social issues (Zeltyn', 2003). State corporations are a relatively new legal phenomenon for Russian legislation, which makes it necessary to conduct a legal analysis of state corporations as subjects of law, their legal status, the legal status of their property and funds, as well as identify the limits of legal regulation of financial control over their activities (Kondrat, 2014). This will determine the effectiveness and feasibility of the existence of public corporations as special subjects of legal relations. The present research studies the ways state corporations use benefits obtained as a result of being a special subject of law and gives recommendations on the necessity of relevant changes to Russian legislation thereof.

The subject of the study is based on the regulatory legal acts defining the legal status of state corporations, the legal status of their property and funds, and the legal regulation of financial control over their activities. The legal basis of the research is in the norms of constitutional, financial, administrative and civil law, including the Constitution of the Russian Federation, the Budget Code of the Russian Federation, the Tax Code of the Russian Federation, the Civil Code of the Russian Federation, federal laws of the Russian Federation, regulations of the Russian Federation, regulatory legal acts of the Ministry of Finance of the Russian Federation, acts of other ministries and departments, as well as regulatory public contracts, in particular: the Federal law «On the Insurance of Household Deposits in Banks of the Russian Federation» No. 177-FZ, dated 23 December 2003, the Federal Law No. 
127-FZ "On Insolvency (Bankruptcy)", dated 26 October 2002, with the Chapter on the Bankruptcy of the Credit Organizations, the Federal Law No. 185-FZ "On the Foundation for Assistance in Reforming the Housing and Communal Services", dated 21 July 2007, the Federal Law No. 270-FZ "On State Corporation "Rostechnologii", the Federal Law No. 317-FZ "On the State Atomic Energy Corporation ROSATOM", dated 1 December 2007, the Federal Law No. 215-FZ, dated 13 July 2015 "On the State Corporation for Space Activities Roscosmos", the Federal Law No. 44-FZ "On the Contract System in the Field of Procurement of Goods, Works, Services for State and Municipal Needs", dated 5 April 2013, the Federal Law No. 223-FZ "On Procurement of Goods, Works, Services by Particular Types of Legal Entities”, dated 18 July 2011, and others.

The theoretical basis of the research represents the scientific works of domestic legal scholars in the field of financial law, constitutional, administrative, civil and international law, as well as the theory of the state and the law, scientific and educational publications on public corporations, and law enforcement practice materials. The sources of the research were studied in the archives of the State Library of the Russian Federation, OECD library, funds of the National Library of the Russian Federation, scientific library of the Moscow State University and the President Library.

The following general scientific methods represent the methodological ground of the present article: analysis, synthesis, abstraction, and generalization. The research also uses a number of particular scientific methods: historical-legal, system-functional, formal logical, and statistical. The present research uses sectoral legal methods, such as formal legal method, complex method and doctrinal comparative legal method. The materials of the Russian and foreign law enforcement practice in the field of financial and legal regulation of the activities of the state corporations represent the empirical basis of the current study.

Different researchers tried to explain the role and necessity of such legal entities (Harold, 1926). Smirnova O.S. evaluates state corporations as the means for promoting the economic development of Russia as well as the means for resolving social problems in Russia (Smirnova, 2013). State corporations as subjects of law are formed for the realization of public interests, i.e. to perform socially significant, essential public functions. State corporations perform public functions economically using public funds (Thurston, 1937). The financing of public corporations represents a decentralized public finance fund. Basically, state corporations' funds are owned by the corporations themselves. The ways of spending state corporation funds also differ depending on a need to implement public functions and the goals of the state corporations. Consequently, one can conclude that public corporations provide public services at the expense of decentralized public finance funds to realize public interests defined for each state corporation in the federal law establishing a corporation. Such analysis of the state corporations does not explain the necessity of the use of such organizational form in the country which only 20 years ago 
overcame total control of the state over all business and social activities of the population. Social problems shall be resolved by the government bodies. Public companies with the state participation successfully conduct business activities. Why such business form emerged is still a deep question.

Ashtaeva S.S. distinguishes state corporations depending on the main goals they are formed to achieve. There are corporations with a wide range of activities, such as Rostec, Rosatom or Roscosmos. Others like Olympstroy or the Foundation for Assistance in Reforming the Housing and Communal Services (Housing Corporation) were formed to achieve specific aims. In the case of the state corporation Olypmstroy the only aim was to support Olympic building projects for Sochi 2014. After the Olympic Games, Olympstroy was liquidated. In the case of the Housing Corporation, the aim is to find dwelling places for people living in dilapidated and wrecked premises. However, the range of aims is not a justification of the necessity to create a special or legal state corporation in Russian legislation. The expediency of such legal form is constantly under discussion. Special laws which regulate each of the state corporations separately make the Russian legislation even more bulky and contradictory.

Questions concerning the control and transparency of the state corporations remain unanswered. A question concerning the rational base for emergence of such forms of legal entities creates a discussion itself (Golesorkhi et al., 2019). This article is a survey on the functioning of the state corporations in comparison with other entities with state participation (FGUP, MUP, PAO) and their state procurement.

\section{The Deposit Insurance Agency's Role in the Financial and Pension System of the Russian Federation}

The State Corporation Deposit Insurance Agency (DIA) was established in January 2004 on the basis of federal law. The DIA is huge on financial matters and regulates the wide variety of aspects from banking problems to pension deposits. The DIA aims to ensure operations of the deposit insurance system. The DIA reimburses insured depositors when an insured event occurs, keeps a register of the deposit insurance system's member banks, monitors the accumulation of the deposit insurance fund, including verification of the accuracy of the deposit insurance premiums paid by member banks, and manages the resources of the deposit insurance fund.

The number of the Deposit Insurance System member banks is 763 (as of August 2018). The number of insured payouts that have occurred as of August 2018 is 454. Each year the powers of the DIA are growing wider and wider. The Federal Law «On Amendments to the Federal Law No. 121-FZ "On Insolvency (Bankruptcy) of Credit Organizations" and on Abolishing of Some Legal Acts of the Russian Federation», dated 20 August 2004, established an institute of the corporate receiver/liquidator of failed banks in Russia. The functions of the corporate 
receiver/liquidator were delegated to the DIA. Hence the DIA got a strategic power of participation in the bankruptcy process of financial organizations at the final step of bankruptcy-receivership (Kevin, 2011).

The number of bank liquidation procedures that have been managed by DIA is 640 . Liquidation procedures have been completed in 307 banks. On 27 October 2008 the Federal Law No. 175-FZ «On Additional Measures to Strengthen the Stability of the Banking System up to 31 December 2014» came into force. The law entrusts the DIA with the functions of the resolution of systemically important banks. The Agency has participated in 23 bank resolution projects.

In compliance with the Federal Law No. 422-FZ "On Guaranteeing Rights of Insured Parties in the Compulsory Pension Insurance System of the Russian Federation that are Based on Accumulated and Invested Pension Savings, as well as Identifying and Paying Benefits", dated 28 December 2013 (in effect from 1 January 2014), a special system was established for guaranteeing the rights of insured parties in the compulsory pension system. The DIA was assigned to act as the system administrator.

Seven hundred and sixty-two banks participate in the system of insurance of banking deposits (as of August 2018). But the number of banks with a valid banking license is 431 . The rest of the banks are in the process of liquidation. The policy of the state is to decrease the number of banks in the Russian Federation to 200. Such a strategy is the silent strategy of the Bank of Russia. One can note definite steps to achieve this result. Taking into account that the policy of the Bank of Russia is to decrease the number of banks in the Russian Federation four times from the current number, such power of the DIA means not only financial benefits for the DIA but also a strategic position in the whole financial and economic system of the Russian Federation. Admittance to the Pension savings of Russian citizens, which will never be cashed out with the current politics in the pension system, makes the DIA even more super powerful.

Table 1. Statistics of Insurance Payments for Banking Deposits (compiled by authors based on ASV, 2018)

\begin{tabular}{|c|c|c|c|c|c|c|}
\hline Date & $\begin{array}{l}\text { Number } \\
\text { of Banks } \\
\text { Participat } \\
\text { ing in the } \\
\text { System } \\
\text { of } \\
\text { Insurance } \\
\text { of } \\
\text { Banking } \\
\text { Deposits }\end{array}$ & \begin{tabular}{|l} 
Number \\
of Banks \\
Having \\
Insuranc \\
e Case \\
\end{tabular} & $\begin{array}{l}\text { DIA } \\
\text { insuranc } \\
\text { e liability } \\
\text { for the } \\
\text { Banks } \\
\text { Having } \\
\text { Insuranc } \\
\text { e Case } \\
\text { (billions } \\
\text { RUR) }\end{array}$ & $\begin{array}{l}\begin{array}{l}\text { Number } \\
\text { of }\end{array} \\
\text { Deposito } \\
\text { rs } \\
\text { Having } \\
\text { Right to } \\
\text { Insuranc } \\
\text { e } \\
\text { Compens } \\
\text { ation } \\
\text { (thousan } \\
\text { ds) }\end{array}$ & $\begin{array}{l}\text { Sum of } \\
\text { Insurance } \\
\text { Compensati } \\
\text { on Paid } \\
\text { Cymma } \\
\text { (billions } \\
\text { RUR) }\end{array}$ & \begin{tabular}{|lr} 
Number & o \\
Depositors & tha \\
Applied & fo \\
Insurance & \\
Compensation \\
(thousands)
\end{tabular} \\
\hline
\end{tabular}




\begin{tabular}{|c|c|c|c|c|c|c|}
\hline 01.01 .2009 & 937 & 52 & 16,5 & 372,0 & 10,9 & 72,4 \\
\hline 01.01 .2010 & 925 & 83 & 22,4 & 627,5 & 21,9 & 174,8 \\
\hline 01.01 .2011 & 909 & 99 & 37,8 & 864,4 & 31,3 & 217,6 \\
\hline 01.01 .2012 & 896 & 116 & 59,4 & 1065,4 & 58,4 & 325,4 \\
\hline 01.01 .2013 & 891 & 130 & 73,5 & 1224,5 & 72,7 & 378,3 \\
\hline 01.01 .2014 & 873 & 157 & 198,7 & 2298,1 & 176,6 & 747,7 \\
\hline 01.04 .2014 & 871 & 174 & 246,6 & 2697,2 & 219,7 & 913,2 \\
\hline 01.07 .2014 & 869 & 185 & 319,6 & 3016,9 & 311,2 & 1127,5 \\
\hline 01.10 .2014 & 867 & 202 & 354,5 & 3210,9 & 341,1 & 1204,3 \\
\hline 01.01 .2015 & 861 & 218 & 384,9 & 3446,9 & 379,0 & 1325,8 \\
\hline 01.04 .2015 & 858 & 223 & 411,6 & 3601,3 & 404,9 & 1388,7 \\
\hline 01.07 .2015 & 854 & 243 & 501,2 & 3902,1 & 483,9 & 1539,4 \\
\hline 01.10 .2015 & 849 & 266 & 627,9 & 4245,2 & 590,8 & 1733,5 \\
\hline 01.01 .2016 & 842 & 295 & 827,9 & 5289,4 & 748,3 & 2038,4 \\
\hline 05.02 .2016 & 842 & 302 & 843,5 & 5316,0 & 812,2 & 2145,4 \\
\hline 01.03 .2016 & 838 & 308 & 917,6 & 5507,4 & 882,0 & 2250,4 \\
\hline 08.04 .2016 & 834 & 323 & 969,0 & 5626,6 & 915,1 & 2306,7 \\
\hline 06.05 .2016 & 832 & 332 & 1019,3 & 5835,9 & 964,1 & 2393,5 \\
\hline 01.06 .2016 & 830 & 336 & 1029,3 & 5870,0 & 1001,1 & 2468,6 \\
\hline 01.07 .2016 & 823 & 339 & 1050,0 & 5920,2 & 1026,4 & 2515,5 \\
\hline 01.08 .2016 & 822 & 345 & 1076,2 & 6027,3 & 1045,0 & 2551,4 \\
\hline 01.09 .2016 & 819 & 351 & 1109,9 & 6355,4 & 1074,9 & 2603,5 \\
\hline 05.10 .2016 & 818 & 360 & 1245,0 & 6773,1 & 1117,3 & 2671,5 \\
\hline 03.11 .2016 & 818 & 366 & 1269,3 & 6841,6 & 1225,4 & 2831,4 \\
\hline 01.12 .2016 & 815 & 371 & 1280,1 & 6858,8 & 1255,6 & 2890,2 \\
\hline 16.01 .2017 & 811 & 384 & 1367,2 & 7410,8 & 1339,2 & 3079,5 \\
\hline 01.02 .2017 & 806 & 386 & 1372,4 & 7441,4 & 1351,6 & 3113,1 \\
\hline 03.03.2017 & 806 & 390 & 1383,1 & 7487,1 & 1361,6 & 3143,0 \\
\hline 05.04 .2017 & 805 & 395 & 1406,8 & 7533,8 & 1379,8 & 3177,5 \\
\hline 05.05 .2017 & 801 & 400 & 1478,2 & 7789,8 & 1415,9 & 3226,1 \\
\hline 29.05 .2017 & 795 & 403 & 1479,7 & 7794,5 & 1459,6 & 3291,0 \\
\hline 01.07 .2017 & 793 & 403 & 1480,1 & 7794,6 & 1467,7 & 3309,6 \\
\hline 03.08 .2017 & 789 & 410 & 1690,6 & 8 194,1 & 1603,0 & 3473,5 \\
\hline 05.09 .2017 & 788 & 414 & 1710,5 & 8213,3 & 1676,4 & 3581,7 \\
\hline 04.10 .2017 & 788 & 416 & 1712,2 & 8218,6 & 1692,8 & 3607,2 \\
\hline 03.11 .2017 & 788 & 416 & 1712,7 & 8218,6 & 1699,1 & 3617,9 \\
\hline
\end{tabular}




\begin{tabular}{|l|l|l|l|l|l|l|}
\hline 05.12 .2017 & 785 & 419 & 1721,4 & 8235,8 & 1701,4 & 3635,3 \\
\hline 01.01 .2018 & 784 & 424 & 1746,7 & 8445,4 & 1721,1 & 3650,7 \\
\hline 05.02 .2018 & 779 & 427 & 1747,6 & 8450,5 & 1733,7 & 3679,9 \\
\hline 05.03 .2018 & 778 & 431 & 1758,1 & 8476,7 & 1740,4 & 3696,4 \\
\hline 04.04 .2018 & 777 & 436 & 1790,8 & 8541,8 & 1748,2 & 3711,2 \\
\hline 04.05 .2018 & 774 & 441 & 1802,0 & 8577,2 & 1780,5 & 3755,6 \\
\hline 05.06 .2018 & 769 & 445 & 1814,9 & 8626,9 & 1790,6 & 3771,5 \\
\hline 04.07 .2018 & 767 & 449 & 1834,1 & 8664,1 & 1804,1 & 3791,6 \\
\hline 02.08 .2018 & 764 & 454 & 1857,4 & 8856,0 & 1835,9 & 3847,9 \\
\hline
\end{tabular}

During the year 2017 the DIA faced 41 insured events in respect of the Deposit Insurance System member banks (as compared to 88 in 2016) with the Agency's liability (covered deposits) of 372.6 billion rubles. The payouts amount decreased by $29 \%$ as compared to the year 2016 (from 568.4 billion rubles to 404.3 billion rubles), while the number of depositors that applied for insurance decreased by $35 \%$ (from 986.5 thousand to 637.8 thousand people). In total, for 14 years of Deposit Insurance System functioning, 424 insurance events have occurred; the total amount of insurance liability amounted to 1746 billion rubles to 8.4 million of depositors included into the registers of liabilities of the banks (Figure 1).

Figure 1. Number of Insurance Events and Payouts (2005-2017) (compiled by authors)

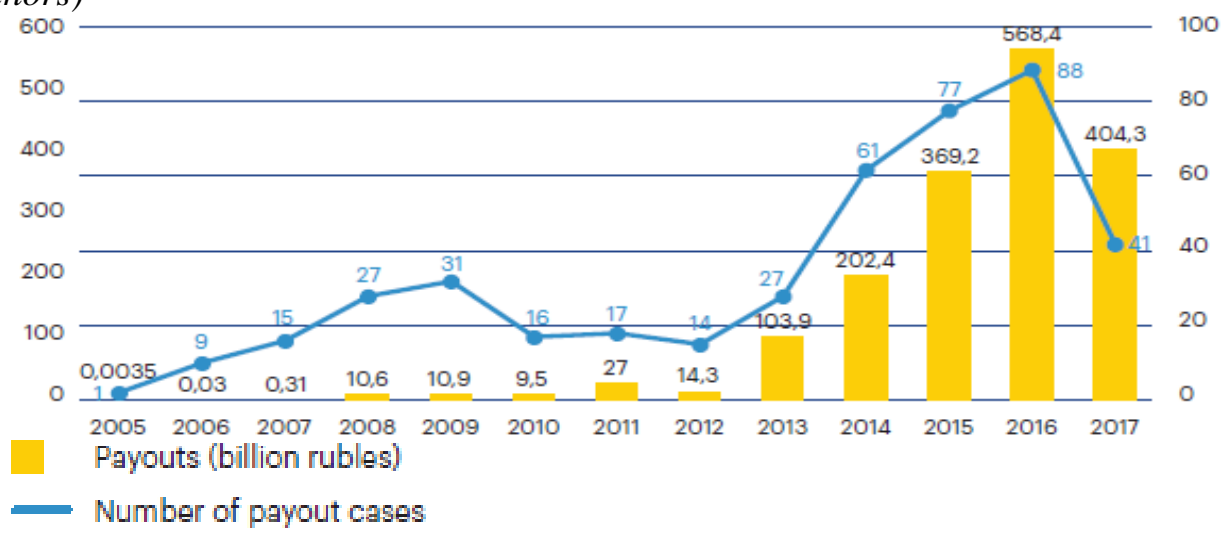

Significant payouts during the reporting period required attraction to the Fund of additional funding in the form of borrowings from the Bank of Russia, the total volume of the Agency's borrowings from the Bank of Russia reached 821 billion rubles as of the end of 2017. Hence the DIA has a direct relationship with the Central Bank of the Russian Federation, and its economic importance and power for both the banks and the population are evident. It accumulates big data information on bank depositors. Such information is vital in assessing the wealth and the buying 
capability of the Russian people, and thus in the strategic planning of the economic development of the country (Gavrilenko, 2014).

Information on the DIA itself can be found on the website of the DIA. It seems public and transparent. But it is transparent only from a global point of view; if one looks deeper, no information on big data storage, real expenses and even incomes of the DIA can be found. One can trace the balance sheet of the DIA as well as its statements of income (losses) and cash flow. But detailed information is not easy to get. The volume and use of the Pension Fund Savings are kept secret. The effectiveness of disposal and accumulation of the funds is questionable. For example, long-term investments of the Pension Savings Guarantee Fund's resources multiplied more than 4 times for the year 2017 compared with the year 2016 (see Table 2). The reasons for such multiplication are not clear.

The DIA is a management company for the pension savings in the Russian Federation under the Federal Law No. 422-FZ "On Guaranteeing the Rights of Insured Persons in the Mandatory Pension Insurance System of the Russian Federation in the Process of Formation and Investment of Pension Savings, and of Payments from such Pension Savings", dated 28 December 2013. The Pension Savings in the Russian Federation is divided into two parts: insurance part (payments which are deducted from the salary and guarantee payments when a person is retired) and accrual part (real money on a personal account of an individual). Employees younger than 1967 (year of birth) dedicate 16 per cent of their salary to the insurance part of the pension and 6 per cent to the accrual part of the pension. That means that the accrual part of the pension savings represents 37,5 per cent of the total pension deductions from the salary.

In September 2013 the Government of the Russian Federation decided to freeze the accrual part in the year 2014, redirecting the funds to the insurance part. On 1 December 2014 and 15 December 2015 President Vladimir Putin promulgated federal laws concerning the freezing of the accrual part of pension savings for the years 2015 and 2016 correspondently. Another federal law froze the accrual part of pension savings until the year 2020. Hence all pension deductions from the salaries of the Russian people come to the insurance part of the pension, the part to be distributed among currently retired persons. Due to the freezing of accrual part, such insurance part shall accumulate 37,5 per cent more than it accumulated before the freezing of the accrual pension part. The incoming part of the pension managed by the DIA shall boost in this case. But one cannot notice such a significant increase in the public documents provided by the DIA. There were no significant changes in the legislation of the Russian Federation concerning the Pension Fund's savings. Hence there are no legitimate answers for many figures given in the reports of the DIA.

To ensure the functioning of the system to guarantee the rights of insured persons, the DIA was empowered to implement the formation of a guarantee fund for pension savings, including collection of guarantee fees and control over the completeness 
and timeliness of receipt of guarantee contributions to the fund to guarantee pension savings, carry out payment of the guarantee compensation, invest the funds of the guarantee fund for pension savings, and exercise the powers of the liquidator and the bankruptcy trustee of the funds' participants.

Table 2. Investment of the Pension Savings Guarantee Fund's resources (compiled by authors)

\begin{tabular}{|l|l|l|l|}
\hline Assets & $\begin{array}{l}\text { As of 31.12.2017 mln } \\
\text { RUR }\end{array}$ & $\begin{array}{l}\text { As of 31.12.2016 mln } \\
\text { RUR }\end{array}$ & $\begin{array}{l}\text { As of 31.12.2015 mln } \\
\text { RUR }\end{array}$ \\
\hline Long-term & 1087 & 256 & 87 \\
\hline Short-term & 27 & 300 & 36 \\
\hline
\end{tabular}

The DIA has a relatively small number of employees. As of the end of 2016, it reports to have a little bit more than a thousand employees; $93,5 \%$ of the employees have a high education, $47,1 \%$ a financial background, and 48 persons a $\mathrm{PhD}$. This shows the relatively high professional level of the DIA compared with other state corporations.

Figure 2. The DIA Employees with High Education (the DIA Report)

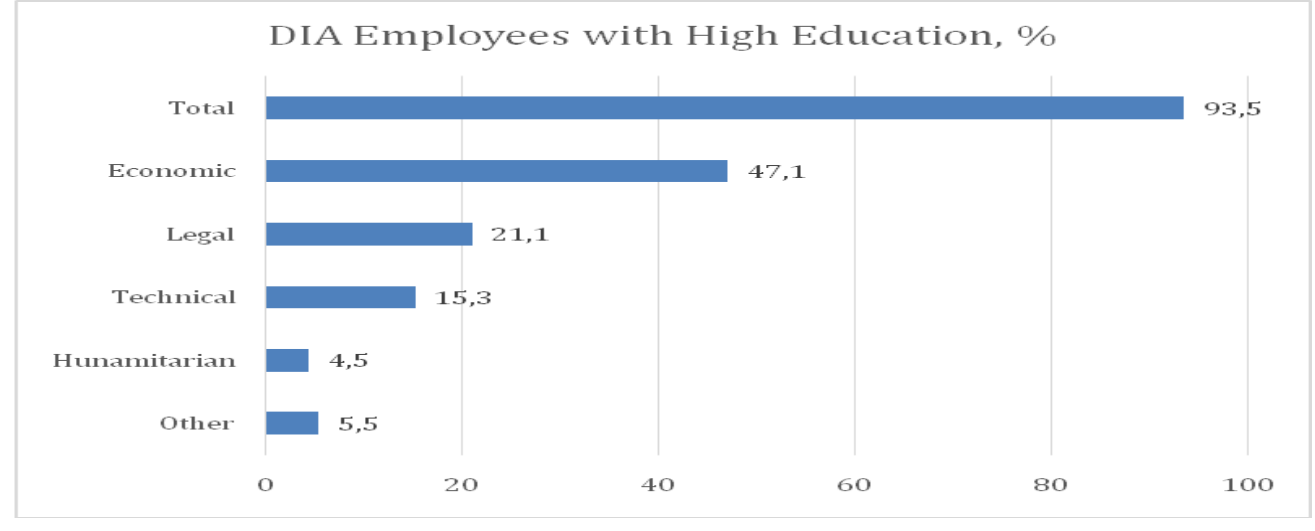

\section{The State Corporation Vnesheconombank Untouchable Mission}

The state's financial activity has always been carried out in two traditional forms: through centralized state cash funds, i.e. budgets (federal, regional) and state extrabudgetary funds (Pension Fund of the Russian Federation, Social Insurance Fund of the Russian Federation, Federal and territorial funds of compulsory medical insurance) and through decentralized state monetary funds, i.e. cash funds of state enterprises, institutions and organizations. The State Corporation "Bank for Development and Foreign Economic Affairs (Vnesheconombank)" (VEB) operates to enhance the competitiveness of the Russian economy, diversify it and stimulate investment activity. Vnesheconombank is not a commercial bank; its activity is governed by the special Federal Law No. 82-FZ, dated 17 May 2007. It is 
specifically stated that the VEB Group does not answer the criteria of "the banking group" or "financial industrial group" in accordance with Russian laws. The corporation received a wide range of functions, significant amounts of state property (funds from the federal budget and the Stabilization Fund; various production and financial assets) ensuring its long-term activities.

The mission of the VEB is to be a driving force of Russia's development and to carry it out through funding investment projects of national significance. The VEB does not compete with commercial credit institutions and participates only in those projects that cannot receive funding from private investors. Under the Memorandum on Financial Policies, the VEB is to extend credits, guarantees and sureties under projects with a payback period of over 5 years and with a total value of more than 2 billion rubles. The VEB is aiming to enhance the competitiveness of the Russian economy, ensure its diversification and promote investment activities, remaining an active member of the global banking community.

The chairman of the highest management body of the VEB is the Head of the Government of the Russian Federation. The VEB has developed a system designed to counteract money laundering and has been using it since 2002. But general information concerning the counteracting of money laundering has certain discrepancies with the data on VEB public procurement.

\section{The Foundation for Assistance in Reforming the Housing and Communal Services (Housing Corporation) and Many Thousand Protests of Muscovites}

The state corporation is based on federal law of the year 2007. The state corporation was supposed to cease operations from 1 January 2013, but the deadlines for the completion of work were repeatedly postponed. In October 2017 the State Duma again extended the Housing Corporation's activities until 1 January 2019. But the current situation with multiple renovation projects all over Russia shows that the Housing Corporation will survive much longer. The Corporation got a negative image in Moscow. Thirty thousand people protested the renovation program on the streets of Moscow in May 2017 and in April 2018. Nowadays the Housing Corporation undertakes rebranding and positive commercials to reinstate its corporate social responsibility image with major stakeholders of the Housing Corporation.

The purposes of the Housing Corporation are stated as to create safe and favorable living conditions for citizens and to stimulate housing and communal services reform, form effective housing management mechanisms, introduce resource-saving technologies by providing financial support at the expense of the Housing Corporation, raise awareness and carry out other activities aimed at educating citizens in the spheres of housing and communal services, and assist in the training 
of personnel in the sphere of housing and communal services (Rjushemajer and Jevans, 2011).

The information disclosed on the Housing Corporation can hardly be called transparent. No information on the funding received and spent is available to the public. No information on public procurement is provided to the general public as well. The commercials on television and in other mass media try to promote the image of the Housing Corporation with strategic corporate social responsibility. In fact, renovation can help people to change their troubled and shabby living premises into new and comfortable ones. The question is - why do people not believe in it? Are they just ungrateful? Do they understand the chance offered to them? The answer is more complicated than it seems to be. The renovation program in Moscow will receive 372 billion rubles. At the same time the law does not allow the renovation of buildings with less than 5 floors. Thus, the renovation program will not benefit those who need it most: shabby and troubled buildings in the Russian regions or even shabby buildings in Moscow. Renovation in the Russian regions is not active at all. Why? Just compare the price of land in Moscow and other Russian regions. The renovation program works and will work only at prime locations where the price of land is growing. Relocation of Muscovites from such places will give private investors a chance to get cheap land for further capital investment and personal enrichment. That will defeat the goal that should transparently be promoted by the Housing Corporation.

\section{The Projects of ROSTEC, ROSATOM and ROSCOSMOS Lie in the State Budget Secrecy}

The same 2007 was a year of the creation of another state corporation ROSTEC. This state corporation aims to assist in the development, production and export of high-tech industrial products by providing support to Russian organizations in the domestic and foreign markets. These organizations include developers and manufacturers of high-tech industrial products. The corporation, by virtue of its predominant participation in these organizations' authorized capitals, or in accordance with agreements concluded between them, or otherwise, has the opportunity to influence the decisions made by these organizations, by attracting investments in various organizations including the defense industry, as well as participation in social and other socially significant projects in the interests of the state and society in accordance with federal laws and decisions of the President of the Russian Federation.

In 2017 the consolidated revenue of the corporation reached 1.59 trillion rubles and shows rapid growth (in 2009 the consolidated revenue of the corporation was 511 billion rubles). ROSTEC includes military and non-military enterprises. Military enterprises prevail, though the share of non-military products in ROSTEC revenue for the year 2017 reached $29.1 \%$. The reported net profit for the year 2017 was 121 billion rubles compared to the reported loss in 2008 of 64 billion rubles. Information 
on military projects and the funds dedicated to them is the state secret of the Russian Federation. One cannot trace such information easily. Social responsibility projects are reported though.

Table 3. Social Programs' Spending (compiled by authors)

\begin{tabular}{|l|l|l|}
\hline Program & 2017 mln RUR & $2016 \mathrm{mln}$ RUR \\
\hline Housing & 793 & 627 \\
\hline Optional Medical Insurance & 1166 & 1177 \\
\hline Non-State Pension Schemes & 919 & 869 \\
\hline Health Resort Services & 655 & 524 \\
\hline
\end{tabular}

Based on the Orders of the Government of the Russian Federation, a number of enterprises of the state corporation ROSTEC received a monopoly on the provision of certain types of services for the state needs. At the same time, they provide services, not directly, but through their contractors. Such intermediary schemes lead to reduced competition and additional budget expenditures.

Another state corporation formed in 2007 under the separate law is ROSATOM. The corporation's stated objectives go thus: to implement the state policy and legal regulation, to provide public services and management of state property in the use of nuclear energy, development and safe operation of organizations of nuclear energy and nuclear weapons complexes of the Russian Federation, organizations operating ships of the nuclear icebreaking fleet technological services, as well as ships with nuclear power plants (nuclear icebreakers and transport vessels), to ensure nuclear and radiation safety, nonproliferation of nuclear materials and technologies, to develop nuclear science, technology and vocational education, implement international cooperation in this field, to implement the state policy in the field of development of the nuclear industry, to fulfil tasks of the state armament program and state defense order (Snytin, 2012).

Since 2009 ROSATOM has developed the public reporting system, which ensures preparation of ROSATOM and its organizations' annual reports in the integrated format, considering Russian and international standards and best practices in this field. ROSATOM's procurement policy strives to increase the efficiency and transparency of the procurement system in the nuclear industry and to minimize expenditures on materials and equipment, including long-lead equipment. To make the procurement process more transparent, ROSATOM has adopted the Uniform Procurement Standard. All corporate orders of ROSATOM are published at www.zakupki.rosatom.ru. More than 360 enterprises of atomic industry are included into the ROSATOM holding (Osipenko, 2013). The employees of the corporation have access to the state secret, as well as certain data of the state corporation itself (Huang, 2018). 
Table 4. ROSATOM Employees (ROSATOM Report) ${ }^{4}$

\begin{tabular}{|l|l|}
\hline Employees & thousand \\
\hline Management & 31,1 \\
\hline Specialists & 98,8 \\
\hline Office staff & 10,3 \\
\hline Workers & 107,1 \\
\hline
\end{tabular}

Figure 3. Number of Employees of ROSATOM with and without High Education (ROSATOM, 2018)

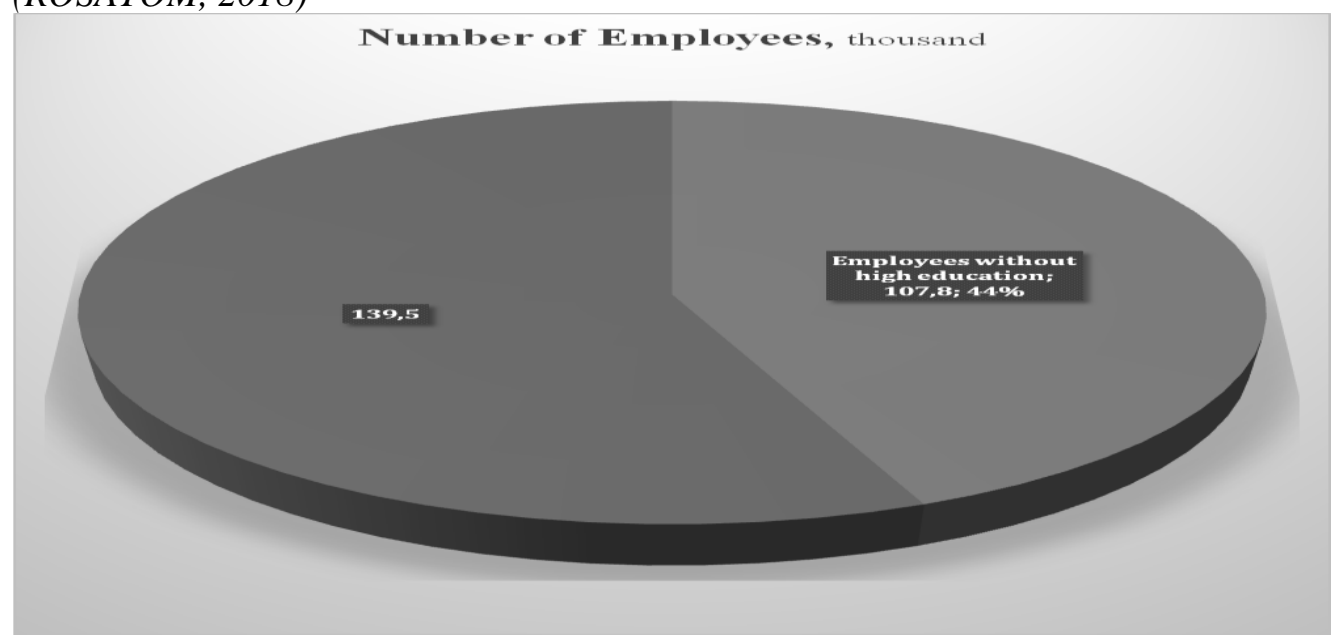

Table 5. Key Performance Indicators of ROSATOM, bln RUR (ROSATOM, 2018)

\begin{tabular}{|l|l|l|l|l|}
\hline & $\mathbf{2 0 1 5}$ & $\mathbf{2 0 1 6}$ & $\mathbf{2 0 1 7}$ & $\mathbf{2 0 1 6 / 2 0 1 7}$ \\
\hline Profit & 821,2 & 878,1 & 967,4 & $+10,2 \%$ \\
\hline Assets & 3160,4 & 3338,7 & 3435,7 & $+2,9 \%$ \\
\hline $\begin{array}{l}\text { Non- } \\
\begin{array}{l}\text { Material } \\
\text { Assets }\end{array}\end{array}$ & 55,9 & 117,6 & 103,5 & $-12,0 \%$ \\
\hline
\end{tabular}

The most recently formed state corporation is ROSCOSMOS, which was founded in 2015. ROSCOSMOS pursues the following objectives: to implement the state policy

${ }^{4}$ Elaborated by the author based on ROSATOM Report for the year 2017 from https://www.rosatom.ru/about/publichnaya-otchetnost/, accessed 6 December 2018. Total number of ROSATOM employees abroad is 1,85 thousand. 
and legal regulation in the field of space activities, to provide public services in the field of space activities and manage the state property, to ensure that the organizations of the Corporation and organizations of the rocket and space industry work to create rocket and space equipment for military, dual, scientific and socioeconomic purposes, as well as strategic missile warfare equipment, to coordinate works on the maintenance, development and use of the global navigation satellite system GLONASS in the interests of special, civil, including commercial, consumers, and to expand international cooperation of the Russian Federation in the field of satellite navigation systems, to implement international activities in the exploration and use of outer space, to implement functions for the overall coordination of work carried out at the Baikonur Cosmodrome and the Vostochny Space Center and to manage these works (Soloduhin, 2013).

As one can see, the state corporation ROSATOM does not publicly announce its net profit or turnover in its annual report for the year 2017, but the report for the year 2014 contained such information. It announces instead its return on assets on net profit and return on sales on net profit. The information on net profit is present on the site of the corporation, but not in the annual report. Instead of the turnover per year one can see the revenue per year.

The area of work of the state corporation is of strategic importance, both for the technological side and the whole country. It is of special importance nowadays when one can observe the struggle for leadership in the Mars program and even in the Moon program between the USA and Russia. Russian scientists are raising doubts as to whether the Americans ever landed on the Moon. The only way to prove their claims is to reach the Moon themselves. Hard work for the success of cosmic travels from the Baikonur Cosmodrome and the Vostochniy Space Center is undergone. The expenses for the program are within the $30 \%$ secret budget of the Russian Federation.

\section{Overall Assessment of the State Corporations}

The overall analysis of the estate corporations suggests that each of the state corporations has numerous structural subdivisions (Stiglitz, 2006), e.g. the VEB had 55 independent subdivisions in Russia and 10 representative offices abroad, the ROSTEC has more than 700 organizations, including 18 holding companies.

The reliability of information on income, property and property obligations of state corporation employees is not sufficiently controlled (Gabov, 2012). The issue of determining the circle of persons whose information about incomes, property and property obligations are subject to publication is not systematic in state corporations. In different corporations the corresponding lists of persons are published on their official websites in different places; they differ greatly and constantly change. 
Table 6. Key Indicators of the Sate Corporations for the year 2017 (compiled by authors)

\begin{tabular}{|l|l|l|l|l|}
\hline Corporation & $\begin{array}{l}\text { Revenue, mln } \\
\text { RUR }\end{array}$ & $\begin{array}{l}\text { Net Profit, mln } \\
\text { RUR }\end{array}$ & $\begin{array}{l}\text { Assets, mln } \\
\text { RUR }\end{array}$ & $\begin{array}{l}\text { Number of } \\
\text { Employees, } \\
\text { thousand }\end{array}$ \\
\hline DIA & 79992 & 4518 & 3706812 & 1,037 \\
\hline VEB & -128100 & 0 & 526800 & 16,807 \\
\hline $\begin{array}{l}\text { Housing } \\
\text { Corporation }\end{array}$ & 29929,33 & 1207,069 & 18,923 & 0,187 \\
\hline Rostec & 1589000 & 121000 & $\begin{array}{l}? 18746,105 \\
\text { gained in 2014 }\end{array}$ & 512,0 \\
\hline ROSATOM & 967400 & 46000 & 3435700 & 247,3 \\
\hline Roscosmos & 25218,52 & 4391,358 & 217011 & 249,94 \\
\hline
\end{tabular}

The state corporations' procurement is regulated by two federal laws: No. 44-FZ of the year 2013 and No. 223-FZ of the year 2011. The Federal Law No. 44-FZ establishes a limited list of procurement methods. It establishes only 10 competitive methods and the possibility of purchasing from a single supplier on the grounds specified in the law. The Federal Law No. 223-FZ allows customers to adopt its internal procurement regulation policy and independently determine types of procurement, e-bidding sites, etc. Only two state corporations, ROSATOM and ROSCOSMOS, actively apply Federal Law No. 44-FZ while effecting procurement and that results in significant money savings. Thus, it shall be advisable to oblige other state corporations to make procurement under the Federal Law No. 44-FZ, e.g. concerning large-scale purchases or to establish a share of competitive purchases from small and medium businesses.

\section{Conclusion}

The conducted research leads to the conclusion that the state carries out its financial activities through the state corporations (Rose-Ackerman, 1999). Such state corporations are specific subjects of legal relations; they provide public services at the expense of decentralized public funds to realize public interests defined for each state corporation in the federal law creating it. Within the framework of the state corporation, the financial activity of the state is transformed into the financial activity of the public entity. The activities of the state corporations are indirect. The state uses indirect mechanisms of state participation through these legal entities in the implementation of public-private partnerships (Roud and Thurner, 2018). The analysis of the main features and characteristics of the state corporations revealed that they are a qualitatively new organizational and legal form in the Russian 
Federation. Such legal form has no specific reference in Russian legislation. Hence, such state corporations can be named entities of public law. Thus, a legal entity under public law is a public institution, the purpose of which shall not be entrepreneurial activity, but a social one concerned with finding solutions to social problems. The state corporations researched are legal entities of public law that have particular authority and are regulated by special laws established individually for a particular corporation. Hence the status of a state corporation is dualistic and combines public law and private law elements.

State corporations as subjects of law are formed primarily for the realization of public interests, i.e. to perform socially significant, essentially public functions. Since state corporations carry out public functions, one can conclude that they provide public services at the expense of public funds. Public expenses are aimed at meeting public interests and represent a set of monetary relations for the distribution and use of monetary means allocated from public funds for each particular corporation specifically. The laws establishing the state corporations do not contain evaluation criteria of the achievement of their statutory objectives (e.g., DIA), or the provided criteria do not allow to monitor the degree of achievement of these purposes with a sufficient degree of accuracy (e.g., ROSATOM, VEB). Moreover, the laws do not contain procedures for long-term planning and measures of responsibility for non-achievement of goals stipulated by the law.

Taking the above into consideration, the authors advise the following amendments to be introduced to the legislation and regulatory acts of the Russian Federation. It is reasonable to supplement the Code of Administrative Violations with an article concerning liability for violation of the obligations of state corporations to prepare and place on the Internet the book-keeping records of state corporations provided for by the legislation of the Russian Federation. The law shall set responsibility for correspondent officials of the state corporations and state corporations themselves for non-publication of book-keeping statements by state corporations, like it is provided for the state and local authorities under Article 13.28 of the Code of Administrative Violations, self-regulatory organizations under Article 14.52 of the Code of Administrative Violations and organizations operating in the financial markets under Article 15.19 of the Code of Administrative Violations.

The research identifies the need for the state to amend the Resolution of the Government of the Russian Federation No. 841 "On compliance by employees of state corporations and state-owned companies with the provisions of Article 349.1 of the Labor Code of the Russian Federation", dated 21 August 2012, on establishing the uniform criteria or imposing on a single state body the obligation to approve lists of positions in state corporations, where employees are subject to the obligation to provide information about their income, expenses, property and property liabilities. The legislation shall oblige state corporations to adopt a single list of positions, where employees are required to submit information about their income, expenses, property and property obligations, as well as income, expenses, property and 
property obligations of their spouse and minor children.

Article 3 of the Federal Law No. 223-FZ "On the procurement of goods, works, services by certain types of legal entities" shall be amended stating the prohibition of legal entities and individuals from having a conflict of interest by participating in procurement. A ban on participation in procurements for state corporations by persons who are affiliated with the customer shall be imposed. Managers of legal entities who own other legal entities that are customers shall be included in the list of potential participants in a conflict of interests. The Federal Law No. 44-FZ shall be applicable to large-scale purchases of state corporations.

The adoption of a unified legislative act regulating the general rules of all state corporations and their powers will resolve part of the problems. Such an act will allow the unified regulation of the legal status of these entities. At the same time the act will focus on the particularities of each state corporation under public law and will provide an understanding of the nature of a state corporation as a special legal form of legal entities.

The implementation of the above recommendations will promote the justification for such legal form as the state corporation both from economic and legal points of view.

\section{References:}

Ashtaeva, S.S. 2012. State Corporations in Modern Russia: Functions, Structure and Activity Particulatities. RAN, 1, $113-116$.

ASV. 2018. ASV reports. https://www.asv.org.ru/agency/statistical_information/

Harold, A. 1926. Government Owned Corporations, New York.

Huang, W.Y. 2018. Influence of Transparency on Employees' Ethical Judgments: A Case of Russia. Journal of Business Ethics, 152(4), 1177-1189.

Gabov, A.V. 2012. Role of Interneural Structures in Fighting Corruption. In: Scientific paper, Moscow: IZiSP, 120.

Gavrilenko, A.G. 2014. Nabiulina Code, Online, 14 Feb., http://gavrilenko.ag/blog/post/20031/

Goldman, M. 2005. Political Graft: The Russian Way. Current History, 313-318.

Golesorkhi, S., Mersland, R., Randoy, T., Shenkar, O. 2019. The Performance Impact of Culture and Formal Institutional Differences in Cross-Border Alliances: The Case of the Microfinance Industry. International Business Review, 28(1), 104-118.

Kevin, R.K. 2011. Federal Government Corporations: An Overview. Congressional Research Service, https://fas.org/sgp/crs/misc/RL30365.pdf.

Kondrat, E.N. 2014. Financial Delicts in Russia. Financial Safety Threats and Ways of Counter fighting. Moscow, Justicinform, Russia, 928.

Osipenko, O.V. 2013. Corporate Control: Experimental Problems of the Effective Governance of Daughter Companies. Book One: Corporate Control Establishment. Moscow, Statut, 520.

Pond, A. 2018. Protecting Property: The Politics of Redistribution, Expropriation, and Market Openness. Economics and Politics, 30(2), 181-210. 
Rjushemajer, D., Jevans, P. 2011. The State and the Economic Reforms: Analysis of the Effective Government Interference. Economic Sociology, 12, 3.

Rose-Ackerman, S. 1999. Corruption and Government: Causes, Consequences and Reform. Cambridge, Cambridge University Press.

ROSATOM. 2018. Rosatom public report, https://www.rosatom.ru/about/publichnayaotchetnost.

Roud, V., Thurner, T.W. 2018. The Influence of State-Ownership on Eco-Innovations in Russian Manufacturing Firms. Journal of Industrial Ecology, 22(5), 1213-1227.

Shashkova, A.V. 2018. Corruption Is a Problem of Political Theory and Practice.

Montenegrin Journal of Economics, 3(14), 143-154.

Smirnova, O.S. 2013. State Corporations as Modern Institute of Russian Economy. Vestnik VolGU, 11(9), 51-53.

Snytin, R.S. 2012. The Role of the State in Forming Innovation in Russian Companies. State Governance, Electronic Book, 31.

Soloduhin, A.K. 2013. The Assessment of the Innovation Programs of Russian Companies with the State Participation. Qualifying Paper, National Research University High School of Economics, Moscow, Russia.

Stiglitz, J. 2006. Making globalization work. American Library Association, 374.

Thurston, J. 1937. The Reconstruction Finance Corporation. Government Proprietary

Corporations in English-Speaking Countries, Cambridge, Harvard University Press.

Zeltyn, A.S. 2003. The Industrial Politics of the State in Market Societies. EKO, 3, 55. 